\title{
An Empirical Study on Competitive Distribution Management of Tea Brands in Bangladesh
}

\author{
Kazi Nazmul Huda ${ }^{1}$, Md. Rezaul Karim ${ }^{1} \&$ Rehnuma Sultana Khan ${ }^{1}$ \\ ${ }^{1}$ Department of Business Administration, Southern University Bangladesh, Chittagong, Bangladesh \\ Correspondence: Kazi Nazmul Huda, Department of Business Administration, Southern University Bangladesh, \\ Chittagong, Bangladesh. E-mail: knhuda@yahoo.com
}

Received: June 5, 2012 Accepted: July 11, 2012 Online Published: September 10, 2012

doi:10.5539/ijms.v4n5p99 URL: http://dx.doi.org/10.5539/ijms.v4n5p99

\begin{abstract}
The study highlights the competitive scenario of the tea market of Bangladesh with special reference to distribution effectiveness of some selective tea brands. This study was conducted in Chittagong, Bangladesh and sample population was chosen from tea selling retailers who sell eight different brands of tea. Ispahani Tea brand was found to be the market leader with the sales figure $34.7 \%$ and Finlay tea brands was found at the bottom of selling table $6.2 \%$, although they both have the best type of tea in the market, scored $4 / 4$ in the product quality scale, and the bestselling brand scored the least i.e. 1. The study shed enough light to the fact that making only good quality product is not enough to sell the maximum or capture market share. Other variables of marketing mixes are equally to be focused with diligent emphasis particularly the distribution management factors. The bestselling brand covered and distributed their tea in more potential and selective areas than the others. The covering of less potential mass market could not bring any fruits for other good brands. With regard to warehousing the study found some problems with rats and cockroaches, otherwise it was fine with storing. More sales call is another factor that also played a vital role in influencing the retailer in occupying shelves and motivating sales.
\end{abstract}

Keywords: competitive, distribution

\section{Introduction}

Marketing involves a complex series of relationship and interactions among the different divisions of an organization (Kansal, P., \& Kapoor, S. K., 2003). Place/distribution are one of the decisive elements in marketing mix leading to ultimate consumer satisfaction. A good distribution network creates a strong competitive advantage for an organization (Piercy, F. N., \& Carvens, D. W., 2006). To create a competitive age in the contemporary marketing scenario, developing effective distribution system is obligatory for the firms engaged in manufacturing fast moving consumer goods. Distribution management demonstrates how this entire process can be managed so as to amplify the efficiency of an organization with its channel members (Kansal, P., \& Kapoor, S. K., 2003). Distribution management is the operation, which creates time, place and form utility through the movement of goods and persons from one place to another (Mossman, F., \& Morton, N., 1965). Further it has been observed that, with growing competition in the market after the emergence of the concept trade liberalization, considerable thought is being given to formulate new market strategies to accelerate and to develop efficient distribution management significantly for the highly convenience beverage like tea.

Tea is the most popular refreshing drink irrespective of age, gender and race. Drinking tea is particularly popular in the northern and southern hemisphere where extreme cold prevails for most of the time. However, Bangladesh is also a good market for tea. Serving a guest with tea is an inalienable part of long-standing Bangladeshi tradition. Bangladesh being a small Tea-producing country shares $2 \%$ of the world's total Tea production. Tea is an agro-based, labor-intensive and export- oriented sector and plays an important role in the national economy through export earnings, trade balancing and employment generation. Tea industry of Bangladesh dates back to 1857 A C when the first Tea garden was established at Malinichera in Sylhet District. Today a total of 163 Tea gardens with an area of 1, 15,757.41 hectors of which 52,317.21 hectors or $45 \%$ is under cultivation (Bangladesh Tea board, 2009).

The domestic consumption of tea in Bangladesh has been enhancing proportionately with demographic growth, which leads to gradual shrinking of our exportable surplus as it eats up the current flow of our tea production. To 
meet this swelling internal demand and to export tea to earn foreign exchange we must maintain at least a 60:40 (Export: Internal consumption) rate to have effective increment in tea production. The low turnover of the existing rate of tea production in Bangladesh may be attributed to the reason of technical, financial and management problems (Bangladesh Tea Board 2009). Effective research needs to be conducted with a view to raising productivity of our tea and improving its quality. Moreover, efficient distribution management is one of the focal points of internal tea marketing in Bangladesh. To serve the local market efficient distribution network is the significant issue for the tea marketers. The study will highlight the distribution management of the marketing giants of tea brands in Bangladesh in the path of competitive and comparative study.

\section{Problem Statement}

Place or Distribution of marketing function acts as a bridge connecting customers and products through wholesalers, retailers or other partners in the distribution systems (Ali M., 2008). Modern marketers are constantly giving emphasis in developing and expanding their distribution network to be competitive in the market, significantly in the commodity goods sector. Tea is one of those commodity products that have created a very competitive scenario in the consumer market of Bangladesh. Market leaders and challengers are battling for the sustainability of their tea brands and targeting the channel members to explore their marketing opportunities. It is obvious that the distributors and the retailers play an effective role in influencing the ultimate customers in their buying behavior. The epicenter of this discussion is to delve out the tea manufacturing companies that are in lead to the existing market players and their current performance to seize opportunities through effective distribution management. Effectively managing the entire distribution process is critical to financial success and corporate longevity (www.investopedia.com, 2012). Once upon a time the M.M Ispahani Ltd. is believed to be the champion in retail tea sales, and subsequently they captured a large portion of our domestic tea market. Ispahani's market share stood at $60 \%$ those days. But on account of restructuring of UNI-LEVER BANGLADESH and other new tea brands operations and marketing, it is slowly regaining the market share by introducing new features in their product. The companies are concentrating more on the distribution efficiencies and offering different packages to the retailers and wholesalers to be competitive in the market.

\section{Objectives of the Study}

The objective of this study is to identify the problems in distribution management of branded tea and to suggest remedial measures to increase sale and market share of these competing tea brands. The study focuses on the following points with the aim to correct some problems in channel management and physical distribution of tea brands.

1) To determine the triggers and barriers for stocking up branded tea.

2) To identify the strength and weakness of distribution channels of the competing brands.

3) To identify the market size (retailers, wholesalers) and determining the market share.

4) Identify the stock depth of the retailers and the position (shelf space) of the brands in the retail stores.

5) Determine the pricing strategies, trade margins and trade deals of the brands.

6) To identify the growth rate of the brands in relation with distribution coverage (in \%) currently attained and the frequency of direct coverage of the distributors.

7) Identify the proper store outlet and to find convenience distribution channels.

\section{Literature Review}

\subsection{Distribution}

Distribution is the key external resource and much as the internal operations, research, engineering and production. Effective distribution is the process which determines the best placement of finished goods, inventories and selects the appropriate modes of transportation for serving the external supply chain (Krajewski, L. J., \& Ritzman, L. P., 2000). In this modern economic era, distribution is one of the strong determinants in developing effective supply chain management system.

\subsubsection{Distribution Management}

Competitive distribution management plays a key role in market penetration and concentration to sustainable profitability through internal and external customer satisfaction. Distribution Management System is the process which simplifies and manages each phase of distribution chain from customers, ordering, delivery, payment, inventory, and right through to services management. Effective distribution management oversees the movement of goods from supplier or manufacturer to point of sale. It is an overarching term that refers to numerous 
activities and processes such as packaging, inventory, warehousing, supply chain and logistics (www.investopedia.com 2012).

Becoming cost effective is also a great challenge for modern marketers to be competitive in the market and to be cost efficient marketers are experimenting with branding, price cuts, promotional blitzes but the only area left in this business is physical distribution, which is also termed as "fat" (Staley, J. R., 1964).

Efficiency in distribution management could be defined as the movement of goods from producer to consumers at the optimal cost consistent with the provision of the desired customer service. Distribution efficiency also means to provide greater consumer value more than optimization of cost.

Effective distribution is widely accepted strategy for new products, managing international distribution channel and specifically when the product marketing is relatively difficult both in the scale of logistics and networking. Reputed manufacturers generally use self sustained distribution management system rather than independent or outsourced distribution network, when it is fully equipped, confident and capable both financially and with human resources. However, distribution and transportation are also termed as 'the economy's dark continent and the last frontier of cost reduction in American business (Drucker P. 1962). It implies that, at some stage marketing managers fails to adjust prices, labor or material cost in bringing efficiency and effectiveness in distribution management. Importantly effective distribution involves two operational areas. 1. Selection of the channel of distribution and 2. Physical distribution (Banerjee M. 1981). From the above literature we can functionalize the distribution management into two border part. Number one is Channel Management, which is more focused to policies and strategies of distribution and number two is physical distribution that aims to bring operational efficiency to maximize value of all the stakeholders involved in the distribution network. Channel management and physical distribution acts as gear wheel that drives the rotating activities of distribution management (figure 1) and the functions of channel management and physical distribution represents the "cogs" of the gear wheel (Table 1).

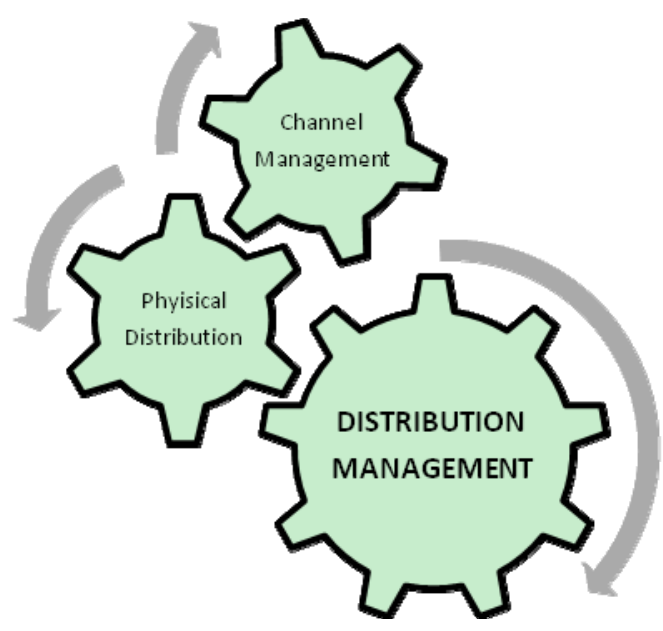

Figure 1. Functions of distribution management

\subsubsection{Channel Management}

A marketing channel is the path a product or service takes as it moves from the manufacturer to its end users or customers (Rolnicki, K., 1998). Effective channel management is a cooperative marketing strategy in which manufacturer augment their direct and indirect channels of distribution to reach different segments more efficiently and effectively (Brigham, F. G., \& Gomes, R., 2001). Current channel management concepts focus of efficiency in cost optimization and effectiveness through better customer satisfaction. Channel Management involves the development of policies and procedures to gain and maintain the cooperation of institutions within the distribution channels. (Boyd, H. W., \& Walker, O. C., et.al, 2002). Depending on the state of the demand in the market, channel management ensures efficiency or responsiveness strategy to maximize excellence in developing distribution network, pricing, financing and other relevant decisions. 


\subsubsection{Physical Distribution}

Physical distribution is the sequence of operation that begins with the transmission of the complete product in its primary packaging to the warehouse, holding it in stock until need, packaging it into secondary parcels or containers, loading into vehicles and delivery it into customer or intermediaries. (Williamson, R. J., 1979). The term "physical distribution" refers to that portion of the total distribution activity devoted to the addition of time and place utility to the form utility provided by manufacturing. It is to be noted that improvements in distribution technology have not kept pace with improvements in manufacturing efficiency and marketing effectiveness. Much has been spoken on marketing but the subject of distribution should be placed in proper perspective for marketing management.

Physical distribution is the "Science" of business logistics whereby the proper amount of the right kind of product is made available at the place where demand for it exists (Johnson et al., 1974). So, distribution is the key link between producing and demand fulfillment. As such it has a profound effect on the success of both activities, and consequently on the basic profitability of the enterprise.

Table 1. Functions of channel management and physical distribution

\begin{tabular}{lll}
\hline s/no & Channel Management & Physical distribution /Logistics \\
\hline 1 & Channel Member Selection & Shipment \\
2 & Communication (Information Systems) & Inventory management \\
3 & Coordination \& Conflict Management & Packing \\
4 & Distribution Network Planning \& Design & Order Processing (Sales order service) \\
5 & Educational activities (Training \& Motivation) & Transportation \& Traffic Management (Selection of \\
& & Transportation Modes, Routes) \\
6 & Pricing & Material Management (Purchasing) \\
7 & Promotional activities & Warehousing \\
8 & Trade Financing & Revisers Logistic \\
\hline
\end{tabular}

\subsection{Bangladesh Tea Scenario}

Though our tea industry suffered a serious setback in 1971 but we succeeded in reversing with the help of the government, foreign assistance and hard work of our planters. It is hoped that to increase local production to an average of $1500 \mathrm{Kg}$ per hector in a few years time and some pragmatic measures to be taken to improve the quality of tea by extending the area with new varieties of hybrid clone, modernizing factories and improving infrastructure. Bangladesh now annually produces average 60 million $\mathrm{Kg}$ of Tea and it was expected to increase the production to 90 million $\mathrm{Kg}$ in the next 15 years (Table 2 and 3).

Marketing of tea in Bangladesh is a process of selling manufactured tea in bulk from tea estates to the buyers through Chittagong Auction who sell it in the local market or export it to other countries either in bulk or in packets. Some of the teas are also sold at estate level with prior permission of Bangladesh Tea Board either directly to overseas buyers or to the internal traders. Tea Auction is held on usually every week at Chittagong, a major port city of Bangladesh with sufficient warehouse and port facilities and well connected by road, railways and air. Tea Traders Association of Bangladesh organizes the weekly tea auction in Chittagong through the appointed tea brokers of Bangladesh Tea Board.

Table 2. Annual growth rate of tea production in Bangladesh

\begin{tabular}{llll}
\hline S/L & Year & Production (In million kilogram ) & Growth Rate \\
\hline 1 & 2004 (Base year) & 56.00 & 100 \\
2 & 2005 & 60.14 & 107.39 \\
3 & 2006 & 53.41 & 95.38 \\
4 & 2007 & 58.19 & 103.91 \\
5 & 2008 & 58.66 & 104.75 \\
\hline
\end{tabular}

Source: Bangladesh Tea Board. 
Table 3. Annual production target achievement (2009 to 2012)

\begin{tabular}{llll}
\hline & Year 2011-12 & Year 2010-11 & Year 2009-10 \\
\hline Production target & 60,500 & 60,000 & 59,500 \\
Achievements & 39,649 & 60,624 & 59,114 \\
\hline
\end{tabular}

Source: Bangladesh Tea Board.

\section{Methodology}

\subsection{Estimation (Models to Be Used)}

According to the present field data sampling statistic method is used in following steps.

1) Observe an important different: Looking for difference between two samples. These two samples are M.M Ispahani LTD brand and UniLever Bangladesh brands.

2) Calculate the appropriate statistic: Summarizing and quantifying the observed differences in statistical data.

\subsection{Research Design}

Exploratory research method is used by assuming number of factors, like the product may be inferior in quality or style, the wrong channels of distribution may be used, the number of sales representatives in the field may be too few and the sales representatives may not be that much efficient and so on. As the study aims to find out the effectiveness of distribution management system of tea brands, it was necessary to cover the entire geographical domain of Bangladesh and to get the actual scenario obviously all the competing tea brands. But for the constrain of time and budget the study covers only the Chittagong metropolitan city of Bangladesh and will highlight the foremost competing brands MM Ispahani Ltd. and UNI Lever Bangladesh Ltd. The Study was carried out among the wholesalers and the retailers.

Table 4. Sources of required data

\begin{tabular}{lccc}
\hline Types of data & Wholesaler & Retailer & Competitors Report \\
\hline Market Size & $*$ & $*$ & $*$ \\
Market share & $*$ & $*$ & $*$ \\
Stock depth of Retailers & $*$ & $*$ & $*$ \\
Pricing strategy & $*$ & $*$ & $*$ \\
Trade deals & $*$ & $*$ & $*$ \\
Growth rate & $*$ & $*$ & $*$ \\
Distribution coverage & $*$ & $*$ & \\
Proper outlet & $*$ & & \\
Frequency of distribution & $*$ & & \\
\hline
\end{tabular}

To brining accuracy in data collection, Chittagong metropolitan City were divided into ten sectors and each sector covers ten (10) outlets, which were selected randomly to enable unbiased response. The sample size was One hundred (100) in number.

\subsection{Data Analysis \& Findings}

Primary and secondary data were collected as per schedule planed earlier and tabulated for analysis accordingly. The deviation and variation in data were well found depending on the different market characteristics. The collected data are according to the view about the overall tea sector of the country might vary. In the research questionnaire, the main concentration was paid on the information needed for the study. The response was great. All retailers tried to answer the questions except the distributor's price. So it is not included in the paper.

Number of respondents: 100

Gender of the respondents: $100 \%$ of the respondents are male.

\subsubsection{Availability Percentage of Different Brands}

In order to make the data available 100 shops in Chittagong have been covered in this research process through a careful scrutiny and screening, and direct visit to the same.

Available brands in different stores are as follows: 
Total number of sample stores: 100

Table 5. Available tea brands in the retail stores

\begin{tabular}{ll}
\hline BRAND & Percentage \\
\hline Duncan & $6 \%$ \\
Finlay & $64 \%$ \\
HRC & $20 \%$ \\
Ispahani & $97 \%$ \\
Ispahani Zareen & $92 \%$ \\
Lipton Taaza (UniLever) & $96 \%$ \\
Lipton Yellow Label (UniLever) & $68 \%$ \\
Shaw Wallace & $2 \%$ \\
\hline
\end{tabular}

From above table 5, it is clear that Distributors are trying hard to make their product available in every corner of the country. Ispahani Mirzapore (the Brand of Ispahani) is the most available tea in our country followed by UniLever Bangladesh, the main competitor of Ispahani is also at the second position by covering $96 \%$ of the stores.

\subsubsection{Weekly Sales of Different Brands}

The data have been gathered through an interview on the weekly sales of some selected products of the sample 100 shop owners.

Table 6. Brands are sold in the retail points

\begin{tabular}{lll}
\hline BRAND & Sell (in kg) & Percentage \\
\hline Brooke Bond Red Label & 100.1 & $12.2 \%$ \\
Finlay & 50.9 & $6.2 \%$ \\
Ispahani & 285.9 & $34.7 \%$ \\
Lipton Taaza & 212.85 & $25.7 \%$ \\
Others & 178 & $21.2 \%$ \\
Zareen & 170 & $20.2 \%$ \\
\hline
\end{tabular}

Ispahani is the leading brand in our country. The distributor of Ispahani is trying hard to increase the sales quotas. They are providing a good feedback to the retailer about their problems as well as on right delivery-time. These entire pro-marketing activities resulted in higher sales. The credit system is the main trick to click their success. Their vision is that "Sell then pay". So they don't have to worry about the money at the buying point. Pressure of this huge stock leads to sales increase.

In terms of adherence to tea brand, the customer does have a shifting perception of mentality not stubbornly attached to any particular brand or other. If told to try any other brand, one would do so. In that case, the retailers have the maneuvering capacity in influencing the sale of Ispahani tea.

Table 7. Brand ranking as per points of performance/sales

\begin{tabular}{lll}
\hline BRAND & Points & Rank \\
\hline Brooke Bond Red Label & 92 & 4 \\
Finlay & 92 & 4 \\
Ispahani Mirzapor. & 366 & 1 \\
Lipton Taaza (UniLever) & 315 & 2 \\
Zareen & 170 & 3 \\
\hline
\end{tabular}

According to retail-sales report Ispahani ranks second to none in respect of brand standing. Second position goes to UniLever Bangladesh Ltd. but they are expanding rapidly in Chittagong, Bangladesh. Ispahani strategically outclassed its competitors with their price tactics, i.e., the lower price, as they have their own tea gardens. 
Table 8 . Stock depth of the competing brands by the retailers

\begin{tabular}{llll}
\hline BRAND & $\begin{array}{l}\text { Stock } \\
\text { (in kg) }\end{array}$ & No. of stores & $\begin{array}{l}\text { Percentage } \\
\text { Per kg in each store }\end{array}$ \\
\hline Finlay & 57900 & 42 & 1.378 \\
Ispahani Mirzapore (TB) & 10900 & 22 & .4954 \\
Ispahani Mirzapur & 179650 & 83 & 2.287 \\
Ispahani Zareen & 10900 & 50 & 1.4954 \\
Lipton Taaza (UniLever) & 162100 & 81 & 2.001 \\
Lipton Yellow Label (TB) & 21100 & 31 & .6806 \\
Red Label & 99150 & 73 & 1.358 \\
\hline
\end{tabular}

The stock of tea is totally dependent on the retail outlets location, sell, size etc. In residential areas and the markets the sale trend looms higher.

Ispahani is the most popular brand name in Chittagong in terms of sale. The average stockpile per store is at least $2.287 \mathrm{~kg}$.

Closest brand is Lipton Tazza of Uni-Lever Bangladesh. The average stockpile per store is at least $2.001 \mathrm{~kg}$.

In the tea-bag market segment, Ispahani Mirzapore leads the competition at a marginal level in striking comparison with Lipton Yellow Label tea-bag (UniLever). Tea-bags are mostly sold in commercial areas, hotels and restaurants.

\subsubsection{Problem in Storing Tea}

The study brings to light some facts about the problem of tea storing which are as follows:

- $\quad$ No Problem in storing: $90 \%$;

- $\quad$ Problem of Rats: 7\%;

- $\quad$ Problem of Cockroaches: $3 \%$

Most of the retailers are not worried about the problem in storing tea as the sales person of respective tea Brands always replace the non-usable / damaged packets.

\subsubsection{Distributors' Coverage}

With regard to the distributors' coverage the following facts derived at:

The best sales team

- $\quad 16 \%$ Respondents voted for Ispahani.

- $10 \%$ Respondents voted for UniLever Bangladesh Ltd.

- $\quad 74 \%$ Respondents voted for both.

In the opinion of the retailers Ispahani,s sales team is better. But most of the retailers declined to comment about the comparative standing between Ispahani and UniLever Bangladesh sales team performance.

\subsubsection{Most Frequent Callers to Accounts}

According to the respondents that comprised of $11 \%$ of the total interviewed opined that Ispahani sales team have a more frequent calling than Uni-lever Bangladesh (09\%). Again, 80\% of the Respondents are under the impression that both the sales teams call more frequently.

\subsubsection{Problems Facing from Distribution Channel}

The study shows that the distribution channel encounters with the following problems:

Ispahani Problems:

- Call time resentment: No problem $90 \%$ cases.

- When the store is closed $2 \%$.

- Irregular or Never comes 4\%.

- Others / Declined to comment- $4 \%$ 


\subsubsection{Uni-lever Bangladesh}

Problems:

- Call time resentment: No problem $89 \%$ cases.

- When the store is closed $4 \%$.

- Irregular or Never comes 4\%.

- $\quad$ Others / Declined to comment- $3 \%$

\subsubsection{Comparative Distribution Functions}

Alteration and replacement of defective goods are parts and parcel of distribution jobs of any good selling companies. With a comparative study in this case it has been found that-

- Did not change goods that are defective: $3 \%$ (UniLever Bangladesh)

- Did not change goods that are defective: $4 \%$ (Ispahani)

\section{Results}

There are number of ways in which a properly designed physical distribution system can help to generate additional sales volume. Considering all the data found in the questionnaire survey and analyzing the market position and the distributor effectiveness, the following recommendations can be drawn:

1) The competing brands may adopt more credit facility for the retailers.

2) A few changes are required in the sales system for the distributors. The sales team should change their timing according to the convenience of the retailers. They should supply the product right in time and give emphasis on the retailers' requirement, i.e., pro-retailer policy needed to be adjusted.

3) The competing brands may incorporate innovative marketing policies so that they can drive the total consumers toward their tea products. Some promotional marketing activities can be adopted, such as, offering gifts to the retailers against targeted quota achievement within a stipulated time frame. Same tempting offers can be delivered to the customers against a certain volume of products or brands for a limited period of time, or targeting social rituals or marking any seasonal festivals.

4) Proper inventory \& control management required to be implemented at the retail store level. So, the stock shortage / sales wastes could be minimized. This has the double-edged leverages i.e., increasing of both actual sales volume and the level of customer satisfaction.

5) Reduce customer inventory requirements - A responsive distribution system can mean shortened customer order cycles, and consequently reduced customer inventories. Focus to be given on the competitor's activities in this field too. Meaning the customers will get the economic leverages by doing business with.

6) Solidify supplier-customer relationships - A soundly designed distribution system can help to solidify and perpetuate a supplier's relationships with its customers. This can be accomplished through integration of the suppliers' delivery facilities with customer's receiving facilities, consignment of stocks to customer, and other devices of a similar nature.

7) Increase delivery discounts - Sufficient cost could be saved by developing more efficient physical distribution procedures to enable the sharing of part of these savings with customers in the form of increased delivery discounts.

8) Enable expanded market coverage - More efficient distribution operations frequently permit a company to compete more profitably and more effectively in distant markets, or in markets that previously were marginal. In this way the company is enabled to expand its distribution, which leads in turn to increase sales volume.

9) Allow greater concentration on demand creation - The development of a well organized physical distribution activity in which a separate administrative group is established to plan and operate the distribution system can free up marketing and sales personnel - to allow them to concentrate more attention on their basic responsibility, demand creation. In many companies this has led to an expansion in the number of sales offices and a decrease in the number of warehouses, with a consequent reduction in total distribution costs. 


\section{Conclusion}

The betterment of the macro economic scenario distribution management strategy needed to be evaluated to fine-tune the total tea marketing process. The tea market was less focused for long time. But with the potential market growth of tea the competition within is quite notable indeed. The demand for tea is universal and so is the supply. In this connection, the quality matters much in popularizing tea product. The folks desire their refreshment to be perfect and hence the quality of tea should be of standard.

The goodwill of the competing brands in Bangladesh makes the tea marketing process easier. The only variable to highlight here is the quality marketing management. Meanwhile Uni-Lever Bangladesh does in a good position though not possess the top place like that of the Ispahani. The main reason for Ispahani to top the market is their retailer-friendly marketing policy. But the Uni-Lever Bangladesh is also fighting neck and neck. In terms of sales personnel both the companies have already proved efficient \& friendly. But yet, the marketing policy followed by the companies makes some inconveniences for the retailers to store and sale the tea products. The retailers play a key role in tea marketing, as the customers do not mind trying a new brand pushed by the retailers. The happy retailer-pro schemes needed to be introduced to have a positive impact in sales volume hike. However, distribution policy and strategy are required to be adjusted time and again in line with the macro and micro environmental changes that occur in the tea market. As concluding remarks the study suggest the competing companies to be focused in this particular marketing research to attain competitive advantage both nationally and globally with special reference to effective distribution management.

\section{References}

Bangladesh Tea Board. (2009). Retrieved from http://www.teaboard.gov.bd/

David, W. Carvens \& Nigel, F. Piercy. (2006). Strategic Marketing (8th ed.). Mc Graw Hill Companies Inc.

Eugene, M. Johnson, Ray, S. House \& Carl, D. McDaniel, Jr. (1974). Readings in Contemporary Marketing. The Dryden Press, Hinsdale, Illinois, USA.

Frank, G. Birgham \& Roger Gomes. (2001). Business Marketing (2nd ed.). NTC/Contemporary Publishing Group Inc. USA.

Frank, H. Mossman \& Newton Morton. (1965). Logistics of Distribution (1st ed.). Allyn and Bacon Pearson Education, Boston.

Investopedia. (2012). Retrieved from http://www.investopedia.com/terms/d/distribution-management.asp

Ispahani Annual Report. (2005).

John, R. Staley. (September, 1964). Nineteen Ways to Save Time and Money in Distribution. Business Management, 26, 43-46, 72, 74, 76-78.

Kenneth Rolnicki. (1998). Managing Channels of Distribution- the marketing executive's complete guide. American Management association USA.

Lee, J. Krajewski \& Larry, P. Ritzman. (2000). Operations management- strategy and analysis (5th ed.). Addison Wesly Longman Singapore.

Moi Ali. (2008). Marketing Effectively. Dorling Kindersley Ltd, London.

Mrityunjoy Banerjee. (1981). Essential in modern marketing- including marketing in India (1st ed.). Rupa Publishers, India.

Peter Drucker. (April 1962). The Economy's Dark Continent. Fortune, 65, 103, 264, 266, 268 \& 270.

Rajan Saxena. (1999). Marketing Management (3rd reprint).

UniLever Bangladesh Annual Report. (2004).

Willam, M. Pride \& O. C. Ferrell. (1995). Marketing Concepts and Strategies (9th ed.).

Willamson, R. J. (1979). Marketing for Accountants \& Managers. Heinemann, London. 